\title{
Reviewing Innovation Spirit in Nie Er's Music Creation in the Context of New Era and New Ideas
}

\author{
Xiulei Ren \\ Qujing Normal University \\ Qujing, China
}

\begin{abstract}
This article reviews the innovative spirit of Nie $\mathrm{Er}$ in music creation through the new perspective of Nie Er's musical works, the new interpretation of Nie Er's popular language, and the innovation of Nie's nationalized music language. Under the background of new era and new ideas, literary and art workers should continue to advance under the guidance of the innovation spirit of the older generation of artists, and earnestly implement and understand General Secretary Xi Jinping's speeches at the literary symposium and the philosophy and social science conference. Combining the spirit and the needs of the times, we will innovatively introduce outstanding literary and artistic works that meet the aesthetic needs of the times and reflect the characteristics of the times.
\end{abstract}

Keywords-Nie Er; music creation; innovative spirit; new era; new background

\section{INTRODUCTION}

Nie Er, a giant star, has left strong color in the history of modern Chinese music. In his short musical career, he has been adhering to the valuable music quality that sings for the people and screams for the nation, leaving rich artistic masterpiece and valuable national spiritual wealth for mankind. The songs created by Nie Er have caused strong repercussions at that time. And these songs encourage people "not to forget the original heart, continue to move forward" in the context of the new era and new ideas. And then, people constantly strive and struggle for a better life. The songs he created make people unable to forget the suffering people who were oppressed and exploited in the long history of China's modern history. It is hard to forget that the revolutionary martyrs in the struggle for national revolution are not afraid of sacrifice. These martyrs persist in ideals, and uphold the conviction. People always remember that a good life is won by people through firm conviction, tenacious perseverance, hard work, and sacrifice. The fundamental reason is the "newness" in Nie Er's music creation.

\section{A NEW PERSPECTIVE OF MUSIC THEMES}

Nie Er's musical works always run through the revolutionary optimism and reflect Nie's new attitude towards life and art. These works profoundly reveal the contradictions in real life. He also gives hope before the dawn of darkness. Based on this new attitude towards life and art, Nie Er's creative innovation became the most shining part of his songs in music creation. With the perfect integration of a new style, a new melody, a powerful rhythm and music image, music works are novel in form. These works have both rich national characteristics and strong contemporary atmosphere. It has both vivid image characteristics and strict organizational structure. These artistic features have improved the aesthetic value of Chinese songs. Also, it has laid historical foundation for this genre.

In the course of the development of modern Chinese music history, Nie Er was the first to break through the ideas of existing music creation. He innovatively used the musical language of the times, nationality and mass to scream for the proletariat and confide for the working class. He bitterly attacked the oppressed class, and cried out the inner world of the oppressed people. In Nie Er's diary: "Music and other arts: poetry, fiction and drama, represent the public shouting. The public will inevitably demand new content and performance of music, and the composer's new attitude."..."They must abandon the composing habit through several generations. ... According to the different attitudes towards life and art, they would focus on life."... "They would compose a revolution song, while maintaining high-level artistic quality."... "The composers of the old era continue to compose music in accordance with the methods established before the revolution. On the other hand, the musicians of the new era that produced by the revolution focus on life according to different attitudes towards life and art."[1]

Nie Er's musical works are innovative. He has studied hard since his childhood. He is good at absorbing the essence from all the excellent cultural heritages at home and abroad. $\mathrm{He}$ is good at speculation and can experience the voices of all walks of life from the practice of work. Therefore, he could strive for the goal of "fighting for the public". Throughout song creation before the 1920s in China, its objective history determines that China's new music is closely related to Chinese intellectuals in the early stage of development. That is to say, Chinese intellectuals have driven the early development of new Chinese music. Even in the 1920s, the flourishing "worker and peasant singing activities" were also carried out under the leadership of a small number of revolutionary intellectuals. To this end, the music contents of the Chinese new music creations before the 1930s mostly express the spiritual feelings and life pursuits of Chinese intellectuals, as well as the transmission of new ideas and the interpretation and description of real 
life. The works that reflect the reality, destiny and pursuit of the working people are rare.

In that age and situation, Nie Er deeply understood the imperialist aggression, the people's suffering, and the social reality of the national death. He gradually realized that as a revolutionary artist, he must stand on the masses' position and ask himself to correctly deal with the relationship among the society, the times and himself. Nie Er wrote in his diary: "Different life contacts cannot be wrote into the works of life. If we do not exercise the personality, we cannot produce great works." [1] Nie Er stood in the position of the proletariat, paid attention to all aspects of the life of the working class, and successfully used the personalized music language to create dock workers, road workers, textile workers, farmers, rural girls, revolution youth, singers and dancers, newspaper boys in music creation. And most of these subjects are blank except for Zhao Yuanren's two works (selling cloth, God). To this end, Nie Er became the first musician in the history of modern Chinese music to use the musical language to shape the image of the proletariat. What is especially worth mentioning, Nie Er creatively shaped the new female image that deviated from the old society's women (weak, moaning and morbid). - These new females have new ideas, strong patriotism, firm and resolute character. Nie Er first used music works to show women's real life. It was a new breakthrough in the history of modern Chinese music. Nie Er broadens the subject of Chinese music creation. His choice of music theme reflects his own requirements for the real society, and reflects his own artistic conception, world outlook and political position.

\section{NEW INTERPRETATION OF THE POPULARIZATION OF MUSIC LANGUAGE}

The emergence and development of modern Chinese revolutionary songs and mass songs were influenced by revolutionary songs and mass songs produced in the European asset revolution and the workers' movement, especially the influence of Soviet songs. In the first half of the 19th century, bourgeois revolutions broke out in European countries. And a large number of mass songs were produced in the revolution. These songs inherited the tradition of the French Revolution using folk songs to match new words and served the struggle. For example, the work of the Austrian national hero "Andre Hofer", which was born in the early 19th century, was passed to Germany at the end of the 19th century and evolved into "Workers". It was transmitted to Russia in the early 20th century and became a song of "The Youth Guards" during the Soviet Civil War. Later, it was introduced to China, and became the song "Youth Pioneer Team" during the first domestic revolutionary war. In addition, among the mass songs of the first half of the 19th century in Europe, a new phenomenon emerged, namely the vigorous development of workers' songs. These songs emerged while the working class entering the historical arena as an independent class. Most songs reflect the struggle requirements and political claims of the working class, as well as their lives and ideals. The authors of the songs are mostly ordinary workers. The music forms are mainly composed of words and melodies. And they are closely related to folk songs. There are also a few songs that begin to approach the mass song style of modern creation, such as the style of the march, the decomposition of main triad of the melody, and the use of dotted notes. The Soviet mass songs had the greatest influence on Chinese mass songs. They began in the 1920s and were brought back to China by the early proletarian revolutionaries in China. The Soviet music is rich in new ideas. The consciousness revolution of the world revolution and the theory of communist society is guided by the aesthetics of the socialist realism, party, artistic nationality and internationalism. [2] The introduction of songs from Soviet revolutionary songs such as "Youth Guards", "Red Army Is the Strongest", "Comrades, Bravely Advance" is very consistent with Chinese political situations. And there is great response in China. These songs spread to China, infiltrated into the people's lives, and inspired the morale of the soldiers and civilians and the creation of songs. Its magnificent and masculine aesthetic style became the aesthetics feature of Chinese song creation.

The introduction of Soviet revolutionary songs coincided with the rising period of China's struggle for the national revolution, which profoundly affected the creation of Chinese mass songs. The domestic art session spurred the enthusiasm of the masses to participate in the war of resistance and vented social resentment. The prosperity of mass songs with Chinese characteristic emerged. As powerful propaganda tool of ideology and music works serving the masses, they present the characteristics of mass and nationalization. The music creation technique is simple. And it is suitable for widespread singing. The composer made "personalized" creation with his personal perception of the real life of society.

Nie Er is the first artist in the history of modern Chinese music to serve the revolutionary cause of the working class with music and art, and to treat the working class and other working people as the main targets of artistic expression. And he opened the creative process of Chinese music with the proletariat as the object of expression. His music works have the characteristics such as easy-to-understand lyrics, short structure, clear rhythm, melody, and easy-to-learn singing. And it reflects the characteristics such as aesthetics and popularization. The unique perspective of his creation is attributed to Nie Er's profound insight into "popularization" and his connection with the "left wing" literature and art.

The "popularization" in Nie Er's music is not a narrow way of placing Chinese folk music and pentatonic tone in the works. In terms of the subject, "working people" are not the same as "the popularization". Due to the complexity of Nie Er's era, Chinese film and music, Chinese song and dances have developed greatly in the 1930s of China. The bourgeois emerging industries have gradually been established in China. And it has been transformed from single "form" that the peasants would be the main body to "the public" composed of peasants, working class, citizens, handicraft producers, intellectuals, and freelancers. The content of "the public" has changed. And it is inevitable that the music language created by expressing "the public" must change with the change of its content. At this time, it is difficult to use Chinese 
traditional folk music and five-tone music language to comprehensively coverage the musical image of such "mass" group. To this end, Nie Er accurately shapes the music image of different classes and different categories. He boldly draws on the elements of foreign revolutionary songs and marches to construct musical language that shapes the music image for the "mass". This is rarely seen in his songs such as "March of the Volunteers", "Graduation Song", "the Pioneer" and other works. For example, "March of the Volunteers" selects the tone of the horn. And the powerful rhythm makes the music show an impact; as if all the people of the world have heard the old "sleeping lion" stand up. Especially in the introduction part, the songwriter used the decomposition form of the extremely powerful major triad to blow the horn of the march. With the development of the melody of the work as the basis, the songwriter has made changes in the fifth and sixth sentences. And then, it would end the music. And the end of the work echoes unifies and completes with the beginning of the work. The whole work emphasizes the perseverance and determination of the Chinese people to be strong and unyielding and to resist against the war.

Japanese progressive dramatist Akita Ujaku commented on Nie Er: "The popularity of Nie Er's works in China and the popularity of Japanese popular composers are fundamentally different. The difference is in composition style, which is a healthy style. ... His composition has such a strong intensity that his work is not a politically mechanical reflection, but can inspire all people to actively live in their respective jobs." [3]

\section{The InNOVATION OF Music LANGUAGE NATIONALIZATION}

The pursuit of nationalization has followed the development of Chinese music for a hundred years. As the core of the development of Chinese music, it has experienced the exploration and practice period of nationalization since the May Fourth Movement, the development period from New China to the end of the 1970s and multi-expansion period after the reform and opening up. The consciousness of nationalization also developed from the consciousness of saving the country and the nation in the first half of the 20th century to the consciousness of national rejuvenation, and finally to the new development of the world in the second half of the 20th century. The nationalization exploration in Chinese creation before the $1980 \mathrm{~s}$ is reflected in the externalization techniques of composing folk songs and using traditional Chinese music elements. However, it is not deep enough to explore the Chinese national culture and national spirit.

Throughout Nie Er's musical works, in the exploration of nationalization, Nie Er has been working hard to create Chinese music language that can express the real life of people at that time. And then, the creative thinking of music is the innovative ability used by the self-will. Nie Er spent most of his life in the achievements of Yunnan's rich and beautiful ethnic folk music and opera. His love and hard study of folk music made him master the traditional Chinese melody and its tone structure, which laid a solid foundation for his music creation. According to the folk instrumental music "Eight Plates", the national instrumental ensemble music "Golden Snake Dance" was compiled. According to Kunming Dongjing Music "The Old Hanging Chamber", "Green Lake in Spring" was compiled. According to the Yunnan lantern music "Yu Yulang", the female voice solo song "A Female Star" was complied. Nie Er is very interested in the collection and arrangement of folk music and tunes in the process of music creation.

"Do" is an innovative use of Nie Er, Xian Xinghai and Lv Ji. This style was widely used by composers to create mass songs. The birth of "Do" is inseparable from the needs of the times and the innovation of music. Its majestic and exhilarating aesthetic characteristics and the national sentiments with rich local characteristics have become favorable musical weapons that confided the public's voice and inspired revolutionary fighting spirit in the 1930s. This innovative and tonal invention began in the music creation of musicians such as Nie Er and Xing Hai. They were at the moment of the Chinese nation's crisis. Especially in a series of anti-aggressive war songs such as "The March of the Volunteers", "Graduation Song" and "Self-defense", Nie Er used the genre form of the march. In order to strengthen the call-to-action and the atmosphere of the war song, he used the bright rhythm of the March song. On the other hand, five-tone is the basis. It consciously blended into the grand tone and the melody. The melody enhances the characteristics of the times and the mass while maintaining the national style. And it has a majestic, high-spirited and forward-looking musical image. The "Do" came into being. [4] Nie Er skillfully combines Chinese folk music elements, ethnic styles with Western music creation techniques and Western music forms. And he has issued the most powerful shouting for the Chinese people, and wrote the most powerful battle song motivating people to fight heroically.

$\mathrm{Nie} \mathrm{Er}$ is also good at shaping the image and spirit of the working class by capturing the unique tone and rhythm of the working class in working life. For example, Nie Er's songs such as "The Bricks", "Big Pile" and "Playing the Yangtze River" are basically written on the basis of the tone of the labor. "The Road Song" and "Dock Worker" are refined from the tone and rhythm of labor. We can understand some of his lyrical songs, such as "Flying Flower Song" (Sun Shiyi's words, the theme song of film "Feihua Village"), "Village Girl of the Steppes" (Tangna's word, songs of "Escape"), "The singer under the iron hoof" (Xu Xing's word, the episode songs of film "Sons and Daughters in a Time of Storm", "Farewell to Nanyang" and "Mei Niang" (Tian Han's words, the episode songs of drama "Rejuvenation"). These songs also use five tones. The tone is characterized with national style. The nationalized application of the aesthetic of the Chinese public complements each other. It is easy to express the voice of the people, and is also easy to sing.

\section{CONCLUSION}

The songs written by Nie Er are accepted by people in the turbulent pattern of Chinese society. His works have huge ideological propaganda in the fierce social and political movements and struggles, as well as in the process of 
preparing for public opinion. They play an important role in the hardships of China's struggle for national independence. And it has promoted the socialist process and the building of socialism with Chinese characteristics.

General Secretary Xi Jinping said at the celebration of the 100th anniversary of the European and American Alumni Association: "Innovation is the soul of a nation, an inexhaustible motive force for a country's prosperity, and the deepest national endowment of the Chinese nation." Nie Er adheres to the endowment of this Chinese nation, bravely and brilliantly explores and practices new musical forms that can conform to the new era and new life content. And then, it can inherit the tradition innovatively and learn from foreign music forms to shape the characters of different classes, shout for them, and declare war on the world for them. Nie Er's short life burst into eternal light. And he succeeded in establishing the first glorious banner of the great musicians.

Cheng Yun, chairman of the Hubei Branch of the Chinese Musicians Association, pointed out: "The essence of Nie Er spirit is the revolutionary spirit and innovation spirit. ... He understands the mission of the times and expresses the voice of the people with new tones, new rhythms and new structures. ... To learn the revolutionary spirit of Nie Er, we must learn the innovative spirit of Nie Er, unite the two, and let the revolutionary spirit command the innovation spirit. And then, we can further create new music." [5]

We can use famous quote from the famous German composer Beethoven: "Music should ignite the fire in the human mind." We can learn and inherit the spirit of Nie's revolution and innovation. Combining music language with the requirements of the new era, the musicians can ignite people's hearts, create art works matching with the times and the needs of the people, and conforming to the law of communication, high aesthetic value, rich connotation, profound thoughts and exquisite art. The whole nation sings "advance, advance, and advance in the pursuit of a better life!"

\section{REFERENCES}

[1] Nie Er Diary. Zhengzhou: Elephant Press, 2004. 聂耳日记.郑州: 大 象出版社, 2004

[2] [Su] A. Soholm Bialik, Lv Jinzao, Zheng Xiangqun Translation. The History of Soviet Music [J]. Journal of Jilin University of Arts, 1989 (01): 58 . [苏]阿. 索霍尔姆. 比亚利克著, 吕金澡、郑向群译, 苏 联音乐史纲[J].吉林艺术学院学报, 1989 (01) : 58.

[3] Quoted from Wang Yuhe. How to Correctly Understand and Evaluate Nie Er and His Music Creation [J]. National Music, 2002 (06): 11-14. 转引自汪毓和. 如何正确认识、评价聂耳及其音乐创作 [J]. 民族音 乐, 2002 (06) : 11-14.

[4] Fan Zuyin. Research on Nie Er's Rhyme [A]. Yunnan Nie Er Music Foundation, Yuxi Nie Er Music Group. Nie Er Music Research Collection [C]. Beijing: China Federation of Literary and Art Publishing House, 2006: 38. 樊祖荫.聂耳歌曲调式研究[A].云南聂 耳音乐基金会、玉溪聂耳音乐课题组编. 聂耳音乐研究文集[C]. 北 京: 中国文联出版社, 2006: 38 .

[5] Cheng Yun. Taking Nie Er's Style, Innovating Music Style [A]. Academy of Nie Er and Xing Xinghai compilation. 70th Anniversary of Nie Er's Birth [C]. Academy of Nie $\mathrm{Er}$ and Xing Xinghai Publishing House, 1982. 程云.走聂耳路、创新乐风[A]. 聂耳、洗
星海学会编.纪念聂耳诞辰七十周年文集 $[\mathrm{C}]$.聂耳、冼星海学会出 版, 1982 . 